\title{
Evaluation of phytochemical components of various parts of Cola millenii K. Schum
}

\author{
Faith Iguodala AKINNIBOSUN ${ }^{1 *}$ and Bolorunduro Lanre ADEWUMI ${ }^{2}$ \\ ${ }^{1}$ Department of Microbiology, Faculty of Life Sciences, University of Benin, P.M.B 1154, Benin City, Nigeria \\ ${ }^{2}$ Department of Science Laboratory Technology, Faculty of Applied Sciences, Rufus Giwa Polytechnic, P.M.B. \\ 1019, Owo, Nigeria
}

\begin{abstract}
This study is aimed at evaluating the qualitative and quantitative phytochemical composition of various parts (leaf, stem bark, root, seed and pulp) of Cola millenii a medicinal plant of southwestern Nigeria. The bioactive ingredients were extracted using water, ethanol and $n$-hexane in a solvent-percolation protocol. The qualitative phytochemical screening result revealed the presence of alkaloids, saponins and tannins in all the parts of the plant analyzed. Glycosides was found in only the seed and pulp extracts while only the seed, leaf and stem bark contain terpenoids. Also, flavonoids were found in pulp extract only whereas, anthraquinones were not found in all the plant parts. In the quantitative analyses aqueous extracts of the pulp parts contained higher saponins $(1.81 \%)$, tannins $(0.77 \%)$ and flavonoids $(1.12 \%)$ followed by seed aqueous extract which had $0.62 \%, 0.51 \%, 0.70 \%$ and $0.47 \%$ composition of alkaloids, saponins, glycosides and terpenoids respectively. In ethanol extract, pulp extract also had higher percentage of alkaloids $(1.72 \%)$, saponins $(2.24 \%)$, tannins $(1.15 \%)$ and flavonoids $(1.21 \%)$ compared to other parts of the plant however, glycosides was found in higher percentage in seed extracts $(1.10 \%)$ than in pulp $(0.21 \%)$. Moreover, in $n$-hexane extracts of the plant parts, pulp extracts revealed higher percentage of alkaloids $(1.71 \%)$, saponins $(1.40 \%)$ and flavonoids $(0.93 \%)$ followed by stem bark extract whereas glycosides was present in higher percentage in seed $(0.82 \%)$ than pulp extracts $(0.38 \%)$. In all, the pulp and seed extracts of the plant contained more phytochemicals than other parts screened. Moreover, pulp extracts contain higher percentage of these phytochemicals than the other parts except glycosides and terpenoids which were more abundant in seed extracts than the other parts. Among different solvents used for extraction in the series, ethanol had the highest extraction capacity in pulp, leaf and stem bark extracts while $n$-hexane had the best extraction capacity in the seed extract. Thus, $C$. millenii may possess medicinal properties which may be expeditiously utilized in the pharmaceutical industry.
\end{abstract}

Keywords: Cola millenii, phytochemicals, alkaloids, saponins, terpenoids, anthraquinones, glycosides.

\section{Introduction}

Generally, plants that contain any active substance which can be applied as remedy for the management of diseases or which may be used as starter for manufacturing of new drugs are regarded as medicinal plants $[1,2]$. Furthermore, a plant becomes a medicinal plant only when its biological activity has been ethnobotanically reported or scientifically established. Historically, plants have always played a major role in African traditional medicine. Nevertheless, among the vast array of these plant species, only few have been investigated for their chemical composition [3]. The folkloric knowledge of medically important plants passed down from generation to generation usually in oral form has made significant impact in the development of many useful compounds used in the modern medicine system.
Plants are invaluable source of medicines used in the management of several diseases especially in African traditional medical practices. According to the World Health Organization, $80 \%$ of the world population relies on medicine from plants in the management and treatment of various diseases; most of these people are located in African countries. Moreover, about $90 \%$ of people in the developing countries are estimated to be reliant on herbs and medicinal plants for their primary health remedies [4]. Furthermore, Food and Agriculture Organization reported that about a quarter of modern drugs are developed from plants while others are synthetic analogues of the species gotten from plants [5]. More than fifty percent of modern pharmaceuticals are developed from natural products especially from plants $[6,7]$.

The pharmaceutical properties of plants used in traditional medicine can be attributed to the presence of phytochemicals in their tissues [8]. Phytochemicals

\footnotetext{
* Corresponding author. E-mail address: faith.akinnibosun@uniben.edu (Faith Iguodala Akinnibosun)
} 
are the natural compounds present in plants and they interact with nutrients and fibers to form an integral part of human immunity system against various diseases. Phytochemicals are grouped into primary and secondary metabolites, the primary metabolites include sugars, amino acids, proteins, etc. whereas secondary metabolites include alkaloid, flavonoids, steroids, saponin, terpenoids, phenolics, etc. [9]. These substances are reportedly produced by the plants as defense against infectious agents and herbivores as well as for synthesis of new compounds.

Cola millenii K. Schum is a small tree with a low crown of spreading branches and edible fruits found in rain forests. It grows to a height of between $4.5 \mathrm{~m}$ and $18 \mathrm{~m}$, developing either a robust or slender stem with either sparse or bushy foliage. It belongs to the family Sterculiaceae, it is commonly called Monkey kola (English) and "obi-edun" by the Yorubas of southwestern Nigeria. In African traditional medicine, the leaves, flowers, stem and fruit follicles and the bark are used in folk medicine to prepare a tonic used as a remedy for dysentery, coughs, diarrhea, vomiting and chest complaints. In Nigeria, C. millenii is used generally in ethnobotany for the treatment of diarrhea and dysentery [10]. Among the Yorubas of South Western Nigeria, the leaves and fruits of $C$. millenii is used in the treatment of ringworm, scabies, gonorrhea, dysentery and opthalmia [11]. There have been reports of the antimicrobial activities of this plant against human pathogens [12]. Despite several reports about the phytochemical properties and extensive uses of $C$. millenii $\mathrm{K}$. Schum in folk medicine, there is a dearth of information on the quantities or proportion of these phytochemicals in major parts of the plant. Therefore, this research is undertaken to determine the phytochemical composition of different parts of Cola millenii.

\section{Experimental}

\subsection{Materials}

The high purity reagents were obtained from (SigmaAldrich Inc, Missouri, USA) being used as received without further purification.

\subsection{Collection and preparation of plant samples}

The leaf, root, stem bark and fruits of Monkey kola (C. millenii) were harvested fresh from the wild in a forest at Iyere, Owo local government, Ondo state. The plant materials were then authenticated at the Environmental Biology Unit of Science Laboratory Technology Department, Rufus Giwa Polytechnic, Owo and voucher specimens (CMP112IF - C. millenii fruit, CMP1122B - C. millenii stem bark, CMP1123R - C. millenii root and CMP1124L - C. millenii leaf) were deposited at the Department of Forestry Resources Technology, of the same institution. The seed and pulp were removed from the fruit manually using laboratory knife. Thereafter, the plant materials were washed thoroughly in distilled water and air dried for 21 days in the laboratory. The dried samples were then ground into powder with the aid of a mechanical grinder and were stored in clean air- tight containers, and kept in a cool, dry place until required for use.

\subsection{Extraction procedure}

$100 \mathrm{~g}$ portion of the powdered samples was soaked in $300 \mathrm{ml}$ of different solvents (acetone and ethanol) for $48 \mathrm{~h}$ with intermittent stirring using sterile spatula. Thereafter, extracts were filtered through filter paper into sterile containers and then dried using rotary evaporator at $50{ }^{\circ} \mathrm{C}$.

\subsection{Qualitative phytochemical screening}

All the tests described below were carried out on the extracts using the methods described by Harborne [13], Trease and Evans [7], and Sofowora [2].

2.3.1. Test for tannins. $1 \mathrm{ml}$ of the extract was boiled in $10 \mathrm{ml}$ of water and then filtered. An observation of green color on addition of drops of $0.1 \%$ ferric chloride $\left(\mathrm{FeCl}_{3}\right)$ confirms the presence of tannin.

2.3.2. Test for saponins. One portion of the extract was boiled in four part of water $(1: 4 \mathrm{v} / \mathrm{v})$ followed by filtration. The filtrate was diluted with a little water and shaken for froth formation; olive oil was added to the mix and shaking continuously for 3 minutes. Appearance of emulsion confirmed the presence of saponins.

2.3.3. Test for flavonoids. $5 \mathrm{ml}$ of the extract was mixed with $3 \mathrm{ml}$ of $1 \%$ aluminum chloride $\left(\mathrm{AlCl}_{3}\right)$. A portion of $5 \mathrm{ml}$ of dilute ammonia and concentrated $\mathrm{H}_{2} \mathrm{SO}_{4}$ solutions were added sequentially. The disappearance of yellow coloration indicated the presence of flavonoids.

2.3.4. Test for terpenoids (Salkowski test). $2 \mathrm{ml}$ of chloroform were mixed with a $5 \mathrm{ml}$ portion of the extract after which concentrated $\mathrm{H}_{2} \mathrm{SO}_{4}$ solution was gently added. Presence of terpenoids was confirmed with the appearance of a red-brown color at the interface.

2.3.5. Test for glycosides. A portion of $3 \mathrm{ml}$ of the plant extract was treated with $1 \mathrm{ml}$ of glacial acetic acid containing one drop of ferric chloride followed by addition of concentrated $\mathrm{H}_{2} \mathrm{SO}_{4}$ solution. The formation of violet-green layer underneath was taken as the positive test for the presence of glycoside.

2.3.6. Test for alkaloids. A 1:5 (v/v) mixture of the extract and $1 \%$ aqueous $\mathrm{HCl}$ was heated in water bath then filtered hot. The filtrate was diluted with water and 4 drops of Mayer's reagent was added. Conclusions were drawn based on color change.

2.3.7. Test for anthraquinone. The extract and benzene were mixed in ratio $1: 2(\mathrm{v} / \mathrm{v})$, and then $10 \%$ $\mathrm{NH}_{3}$ was added to the filtrate. Appearance of violet color after shaking of the mixture was taken as positive for the presence of anthraquinones. 


\subsection{Quantitative phytochemical determination}

2.4.1. Tannins. A portion of the extract $(2 \mathrm{~g})$ was weighed into a beaker, $20 \mathrm{ml}$ of methanol was added and homogenized by shaking. The beaker was sealed with Parafilm (Bemis Inc, USA) and heated in water bath at $80^{\circ} \mathrm{C}$ for $1 \mathrm{~h}$. The mixture was filtered using Whatman No. 1 filter paper into a volumetric flask then, $20 \mathrm{ml}$ water, $2.5 \mathrm{ml}$ Folin-Denis reagent and 10 $\mathrm{ml}$ of $17 \% \mathrm{Na}_{2} \mathrm{CO}_{3}$ were added and homogenized. This was made up to $100 \mathrm{ml}$ with distilled water and left for $30 \mathrm{~min}$ to react. The absorbance of the tannic acid standard solution along with the sample was measured after color development using spectrophotometer (Buck Scientific 210VGP), at 760 $\mathrm{nm}$ [14]. The percentage of tannin was estimated by the formula:

$$
\% \text { Phytochemical }=\frac{A \times G F \times D F}{m \times 10,000}
$$

where: $A=$ absorbance of sample;

$G F=$ gradient factor;

$D F=$ dilution factor;

$m=$ mass of sample $[\mathrm{g}]$.

2.4.2. Determination of alkaloids. A $2 \mathrm{~g}$ portion of finely ground sample and $1 \mathrm{~g}$ of magnesium oxide were mixed with absolute ethanol and then made up to $100 \mathrm{ml}$ in a beaker. The mixture was digested in a boiling water bath for $2 \mathrm{~h}$ and then filtered immediately with the aid of a Buchner funnel. Further, the residue was re-digested for $45 \mathrm{~min}$, thereafter, the alcohol was evaporated and water was added. After the removal of the alcohol, few drops of $10 \%$ hydrochloric acid was added. The solution was poured into a $250 \mathrm{ml}$ volumetric flask then $5 \mathrm{ml}$ each of zinc acetate solution and potassium ferrocyanide $\left(\mathrm{K}_{4}\left[\mathrm{Fe}(\mathrm{CN})_{6}\right]\right)$ solution were added and homogenized to give a uniform solution. The mixture was left to react for some minutes, and then filtered with Whatman paper. Afterwards, $10 \mathrm{ml}$ of the filtrate was transferred into a separator funnel and the alkaloids extracted by vigorous agitation with five successive portions of chloroform. The precipitate gotten was dissolved in hot water and transferred into a Kjeldahl bottle while $0.20 \mathrm{~g}$ sucrose, $0.02 \mathrm{~g}$ selenium and $5 \mathrm{ml}$ concentrated sulfuric acid were added for digestion to determine percentage nitrogen [14].

The alkaloids percentage was estimated by the formula:

$$
\% \text { Alkaloids }=\% \mathrm{~N} \times 3.26
$$

where: $\% \mathrm{~N}=$ percentage nitrogen

$$
3.26=\text { constant. }
$$

2.4.3. Determination of flavonoids. A portion of $1 \mathrm{~g}$ of finely ground sample was dissolved in $80 \mathrm{ml}$ of absolute ethanol in a beaker with continuous stirring. After, the mixture was filtered with Whatman filter paper and then made up to $100 \mathrm{ml}$ with ethanol in a volumetric flask. $1 \mathrm{ml}$ of this solution was measured into $50 \mathrm{ml}$ volumetric flask and $0.5 \mathrm{~g}$ of magnesium with few drops of concentrated hydrochloric acid were added (magenta red coloration developed). To a fresh standard flavonoids solution ( $5 \mathrm{ppm}$ ) was added $0.5 \mathrm{~g}$ of magnesium and few drops of hydrochloric acid. Absorbance of the sample as well as that of standard solutions were measured on a digital Jenway V6300 spectrophotometer at a wavelength of $520 \mathrm{~nm}$ [14]. The percentage of flavonoids was calculated using Eq. 1.

2.4.4. Determination of saponins. A portion of $2 \mathrm{~g}$ of finely ground sample was dissolved with $100 \mathrm{ml}$ isobutyl alcohol in a beaker and homogenized by shaking for a few hours on an automated shaker. The mixture was later filtered with Whatman filter paper into a clean beaker, $20 \mathrm{ml}$ of magnesium carbonate was added and the mixture was re-filtered. $1 \mathrm{ml}$ of the filtrate was added to $2 \mathrm{ml}$ of $5 \% \mathrm{FeCl}_{3}$ solution in volumetric flask and made up to $50 \mathrm{ml}$ with distilled water. This mixture was left for $20 \mathrm{~min}$ for development of red color. A freshly prepared standard saponin solution (0-10 ppm) was also treated with $\mathrm{FeCl}_{3}$. Thereafter, absorbance of the sample and standard saponins solutions were recorded in spectrophotometer at a wavelength of $380 \mathrm{~nm}$. thus:

The percentage of phytochemical was determined

$$
\begin{gathered}
\% \text { Phytochemical }=\frac{A \times G F \times D F}{m \times 1000} \\
\text { where: } A=\text { absorbance of sample; } \\
G F=\text { gradient factor; } \\
D F=\text { dilution factor; } \\
m=\text { mass of sample }[\mathrm{g}] .
\end{gathered}
$$

2.4.5. Determination of glycosides. A $10 \mathrm{ml}$ portion of each of the extract was mixed with $50 \mathrm{ml}$ of chloroform in a conical flask, the mixture was then shaken for 1 hours using automated shaker then filtered into a conical flask. $10 \mathrm{ml}$ of mixture and $2 \mathrm{ml}$ of pyridine and $2 \%$ sodium nitroprusside $\left(\mathrm{Na}_{2}\left[\mathrm{Fe}(\mathrm{CN})_{5} \mathrm{NO}\right]\right)$ were added to the filtrate and vigorously shaken for a few minutes followed by addition of $3 \mathrm{ml}$ of sodium hydroxide $(\mathrm{NaOH})$ which leads to the development of brown-yellow coloration [14].

Glycoside standards which ranged from 0-5 $\mathrm{mg} / \mathrm{ml}$ were prepared from $100 \mathrm{mg} / \mathrm{ml}$ stock glycoside standard. A series of fresh glycoside standards $(0-5 \mathrm{mg} / \mathrm{ml})$ were also treated with pyridine, sodium nitroprusside and $\mathrm{NaOH}$ like the test samples. Absorbance of the samples and the standards were read on a Spectronic 21D Digital spectrophotometer at a wavelength of $510 \mathrm{~nm}$. 3.

The percent of glucosides was estimated using Eq.

2.4.6. Anthraquinones determination. A $1 \mathrm{~g}$ portion of the sample was dissolved in $60 \mathrm{ml}$ benzene in a beaker with continuous stirring and then filtered. 10 $\mathrm{ml}$ of the filtrate was measured into a volumetric flask where 0.2 zinc dust and $50 \mathrm{ml}$ hot $5 \% \mathrm{NaOH}$ solution were added successively. This was heated in a water bath for about 7 min and then quickly filtered and 
washed once in water. The filtrate was re-heated with $50 \mathrm{ml}$ of $5 \% \mathrm{NaOH}$ until a red color was developed [14].

Fresh standard anthraquinone solution (0-5 $\mathrm{mg} / \mathrm{ml}$ ) was also treated $0.2 \%$ zinc dust and $\mathrm{NaOH}$ like the sample. The absorbance of both sample and the standard anthraquinone solutions were recorded through spectrophotometer (Buck Scientific 210VGP) at a wavelength of $640 \mathrm{~nm}$ and the percent anthraquinone was estimated using Eq. 1.

2.4.7. Determination of terpenes. $20 \mathrm{ml}$ of methanol and chloroform mixture $(1: 2 \mathrm{v} / \mathrm{v})$ was used to dissolve $1 \mathrm{~g}$ of sample in a conical flask, this was homogenized and allow to react for about $20 \mathrm{~min}$ after which it was centrifuged at 1,000 rpm for $15 \mathrm{~min}$. The precipitate was recovered by decantation and later re-washed with another $20 \mathrm{ml}$ methanol-chloroform mixture and centrifuged.

The precipitate was later dissolved in $40 \mathrm{ml}$ of $10 \%$ sodium dodecyl sulfate solution with the addition of $1 \mathrm{ml}$ of $0.01 \mathrm{M} \mathrm{FeCl}_{3}$. The mixture was shaken and allowed to react for $30 \mathrm{~min}$. The absorbance of the freshly prepared standard terpenes $(0-5 \mathrm{mg} / \mathrm{ml})$ solutions and that of the sample was read on spectrophotometer (Buck Scientific 210VGP) at a wavelength $510 \mathrm{~nm}$ [14]. The percent of terpenes was calculated using Eq. 1.

\subsection{Data analysis}

Data were recorded as mean \pm standard error of mean (mean \pm SEM). Significant difference between groups was tested using two-way analysis of variance and treatment means were compared with Duncan using SPSS version 17.0, while significance was taken at $95 \%$.

\section{Results and discussion}

\subsection{Results}

Preliminary phytochemical screening results of various parts of Cola millenii K. Schum is presented in Table 1 where it is revealed that the extracts contain alkaloids, saponins, tannins, glycosides, flavonoids and terpenoids whereas anthraquinones were not found in any of the plant parts analyzed. The pulp and seed extracts of the plant had the highest number (5) of the phytochemicals screened while the root extracts (3) had the least number of the phytochemicals. Among different solvents used for extraction in the series, ethanol had the highest extraction capacity in pulp, leaf and stem bark extracts while $n$-hexane had the best extraction capacity in the seed extract.

Table 1. The qualitative phytochemical components of crude extracts of Cola millenii.

\begin{tabular}{|c|c|c|c|c|c|c|c|c|c|c|c|c|c|c|c|}
\hline \multirow[t]{2}{*}{ Phytochemical } & \multicolumn{3}{|c|}{ Leaf } & \multicolumn{3}{|c|}{ Stem bark } & \multicolumn{3}{|c|}{ Root } & \multicolumn{3}{|c|}{ Seed } & \multicolumn{3}{|c|}{ Pulp } \\
\hline & $\mathrm{AE}$ & $\mathrm{EE}$ & $\mathrm{HE}$ & $\mathrm{AE}$ & $\mathrm{EE}$ & $\mathrm{HE}$ & $\mathrm{AE}$ & $\mathrm{EE}$ & $\mathrm{HE}$ & $\mathrm{AE}$ & EE & $\mathrm{HE}$ & $\mathrm{AE}$ & $\mathrm{EE}$ & $\mathrm{HE}$ \\
\hline Alkaloids & + & + & + & + & + & + & + & + & + & + & + & + & + & + & + \\
\hline Saponins & + & + & + & + & + & + & + & + & + & + & + & + & + & + & + \\
\hline Tannins & + & + & + & - & + & + & + & + & + & - & - & + & + & + & - \\
\hline Anthraquinones & - & - & - & - & - & - & - & - & - & - & - & - & - & - & - \\
\hline Glycosides & - & - & - & - & - & - & - & - & - & + & + & + & - & + & + \\
\hline Flavonoids & - & - & - & - & - & - & - & - & - & - & - & - & + & + & + \\
\hline Terpenoids & - & + & + & - & + & + & - & - & - & + & + & + & - & - & - \\
\hline
\end{tabular}

Legend: $\mathrm{ND}=$ not detected; $+=$ present; $\mathrm{AE}=$ aqueous extract $\mathrm{EE}=$ ethanol extract; $\mathrm{HE}=n$-hexane extract.

The results of quantitative evaluation of the phytochemicals in the different parts of the plant are presented in Figures 1 to 3 . Fig. 1 shows that in aqueous extracts of the plant parts, saponins $(1.81 \pm 0.01 \%)$, tannins $(0.77 \pm 0.00 \%)$ and flavonoids $(1.12 \pm 0.01 \%)$ were present at a higher percentage in aqueous pulp extract of Cola millenii followed by seed aqueous extract which had $0.62 \pm 0.00 \%$, $0.51 \pm 0.01 \%, \quad 0.70 \pm 0.01 \%$ and $0.47 \pm 0.01 \%$ composition of alkaloids, saponins, glycosides and terpenoids respectively.

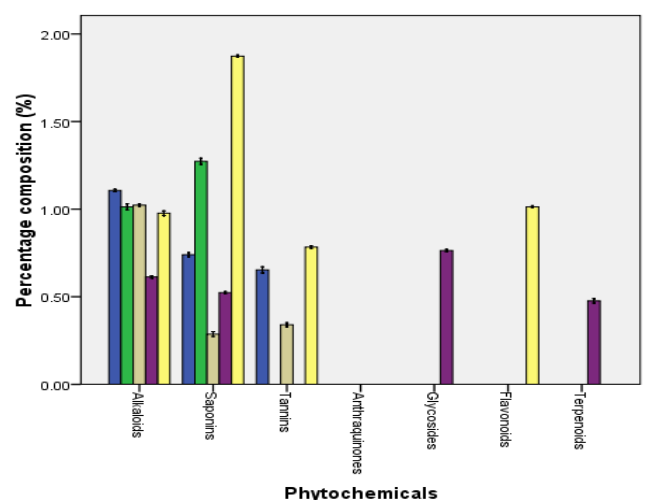

Figure 1. Phytochemical composition (\%) of Cola millenii aqueous extract. 


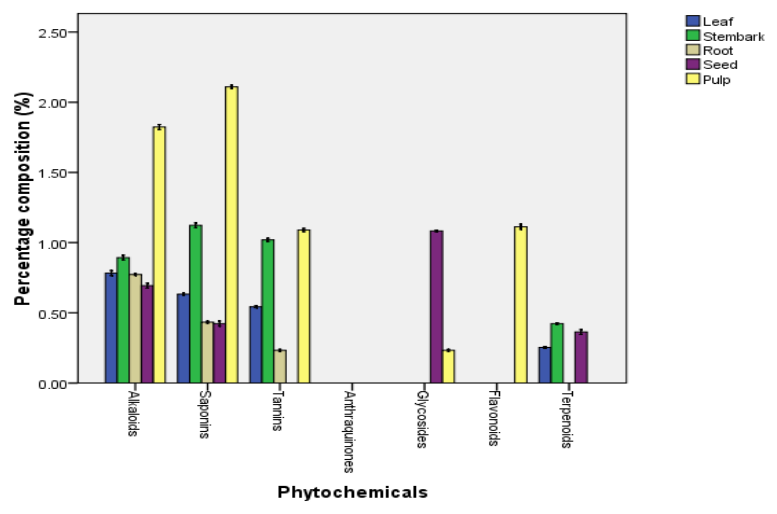

Figure 2. Phytochemical composition (\%) of Cola millenii ethanol extract.

In crude ethanol extract of the Cola millenii parts, pulp extract contain higher percentage of alkaloids $(1.72 \pm 0.01 \%)$, saponins $(2.24 \pm 0.00 \%)$, tannins $(1.15 \pm 0.02 \%)$ and flavonoids $(1.21 \pm 0.01 \%)$ compared to other parts of the plant however, glycosides was found in higher percentage in seed extracts $(1.10 \pm 0.00 \%)$ than in pulp $(0.21 \pm 0.00 \%)$.

In $n$-hexane extracts of the plant parts, pulp extracts contained higher percentage of alkaloids $(1.71 \pm 0.00 \%)$, saponins $(1.40 \pm 0.01 \%)$ and flavonoids $(0.93 \pm 0.00 \%)$ followed by stem bark extract whereas glycosides was present in higher percentage in seed $(0.82 \pm 0.00 \%)$ than pulp extracts $(0.38 \pm 0.01 \%)$.

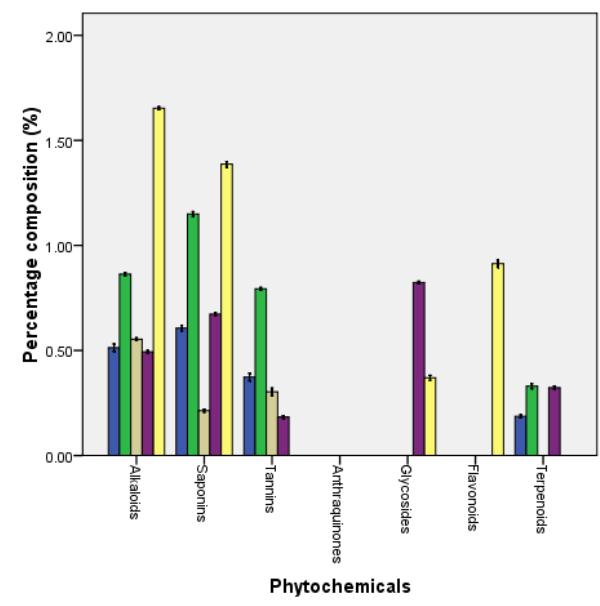

Figure 3. Percentage phytochemical composition of Cola millenii $n$-hexane extract.

\subsection{Discussion}

Phytochemicals are natural bioactive compounds produced by plants as secondary metabolites that work with nutrients to protect against pathogenic attacks. To survive in the harsh environment that plants live, they often synthesize various kinds of secondary metabolites that act to ameliorate such situations [15]. Nascimento et al. [16] reported that phytochemicals represents the most abundant and extensively distributed substances in the plant kingdom and that several plants and herb cells produce and father these range of medicinal phytochemicals. Cowan [17] and Cheeke [18] opined that some of the phytochemicals have great medicinal functions which play major roles in the new drug development process.

The presence of alkaloids, saponins, tannins, glycosides, flavonoids and terpenoids in seed and pulp of $C$. millenii in this present study is in consonance with the reports of earlier researchers [19, 20]. However, Ubon et al. [19] did not find flavonoids, tannins and anthraquinones in C. millenii seed they examined while Giwa et al. [20] did not find flavonoid and anthraquinones in the seed and pulp of C. millenii they screened. Ajayi and Ojelere [21] also reported the presence of terpenoids in the seed of $C$. millenii which is in conformity with the result of this research.

On the basis of distribution, the phytochemicals were found in varying quantities in the plant parts examined. Alkaloids and saponins were found to be higher in all the plant parts compared with the other phytochemicals. The presence of these secondary metabolites in high proportions suggests that the plant parts may possess pharmacological properties since alkaloids and saponins are two of the most revered phytochemicals in plants.

Alkaloids are believed to be one of the most effective and therapeutically significant plant substances [22], they are reported to be pharmacologically active and their actions are felt in different parts of the body system such as the nervous system, blood vessels, promotion of diuresis, respiratory system, gastrointestinal tract, uterus, malignant diseases and malaria [7, 15]. This may explain the use of the plant parts especially the seed, pulp and leaf in treating several disease conditions $[12,23]$. Alkaloids have analgesic, antiplasmodial and bactericidal effects [24] as well as marked physiological effects on animals [25]; this supports the folkloric use of the $C$. millenii pulp in treatment of various diseases in monkey.

Saponins have hypotensive and cardiac depressant properties according to Olaleye [26] and have been shown to possess beneficial properties by lowering the cholesterol level, have anti-diabetic and anticarcinogenic properties as well as being used as an expectorant and emulsifying agent $[15,27]$. The high percentage of saponins in the leaf, stem bark, seed and pulp of $C$. millenii suggests that the plant may be useful in the treatment of diabetes and management of heart conditions.

The presence of tannins in high percentage in pulp and stem bark of the plant indicates that plant may be useful in the management of infectious diseases. Tannins are reportedly efficacious as antimicrobial agent [24] and to stop bleeding during circumcision. The skin regeneration actions of tannins could explain the usefulness of the plant wound healing [28]. 
Terpenoids were found in the leaf, stem bark and seed of $C$. millenii. They reportedly possess antihepatoxic properties, thus helping to prevent liver damage (cirrhosis); they equally have anti-microbial or anti-septic properties [15]. This suggests that the plant may be useful in the management of liver problems.

Interestingly, flavonoids was found only in the pulp extract of $C$. millenii, this is line with the reports of Ajayi and Ojelere [21], but at variance with the observation of Giwa et al. [19] who did not detect flavonoids in either seed or pulp extracts of $C$. millenii assayed. The presence of flavonoids in the pulp extracts of the plant is supported by earlier reports that flavonoids are found generally in plants. They are said to be produced by plants in response to microbial infection [15]. They are also known for their antioxidant, anticarcinogenic, antimicrobial and antitumor properties [29]. This may be an indication that $C$. millenii may possess the ability to boost the immune system.

Moreover, glycosides were found in seed and pulp of $C$. millenii albeit significantly high only in seed extract, this is in line with the reports of Giwa et al. [20], Ajayi and Ojelere [21] and Ubon et al. [19]. Glycosides are reported to possess clinical effects on congestive heart failure [15]. They are also said to be active on the heart muscles and increase renal flow (diuresis) [26]. All these are pointers to the potential ability of the plant part especially the seed to manage several degenerative diseases.

\section{Conclusion}

From the foregoing, various parts of Cola millenii K. Schum contain alkaloids, saponins, tannins, glycosides, flavonoids and terpenoids whereas anthraquinones was not detected in plant's parts analyzed. The pulp and seed extracts of the plant contained more phytochemicals than other parts screened. Moreover, pulp extracts contain higher percentage of these phytochemicals than the other parts except glycosides and terpenoids which were more abundant in seed extracts than the other parts. Among different solvents used for extraction in the series, ethanol had the highest extraction capacity in pulp, leaf and stem bark extracts while $n$-hexane had the best extraction capacity in the seed extract. Thus, C. millenii may possess medicinal properties which may be expeditiously utilized in the pharmaceutical industry. However, there is need for further research to elucidate the chemical species present in the various parts of $C$. millenii.

Conflicts of interest: The authors declare no conflict of interest.

\section{References}

[1]. S.P. Bako, M.J. Bakfur, I. John, E.I. Bala, Ethnomedicinal and phytochemical profile of some savanna plant species in Nigeria, International Journal of Botany 1 (2005) 147150.

[2]. A. Sofowora, Medicinal plants and traditional medicine in Africa, 2nd edition, pp. 134 - 156, Spectrum Books Limited, Ibadan, Nigeria, 1993.

[3]. F.B. Salisbury, C.W. Ross, Plant Physiology. pp. 357-407, Wadsworth, 1992.

[4] World Health Organization, Traditional medicine - growing needs and potentials, WHO Policy Perspectives, 2002.

[5]. Food and Agriculture Organization, Non-wood news: An Information bulletin on Non-wood forest products, p. 25, 2000.

[6]. A.A. Elujoba, O.M. Odeleye, C.M. Ogunyemi, Traditional medical development for medical and dental primary health care delivery system in Africa, African Journal of Traditional Complementary and Alternative Medicine 2 (2005) 46-61.

[7]. G. Trease, W.A. Evans, Textbook of pharmacognosy, 13th ed., pp. 19-21, Bailliere Tindall Ltd., London 1989.

[8]. S.Q. Ayodele, The effects of herbal remedies. Paper presented at the 12th Annual Conference of the Botanical Society of Nigeria (BOSON), University of Lagos, pp. 21-29, 2003.

[9]. A. Sumathi. Evaluation of physiochemical and phytochemical parameters of Melia azedrach. L leave (Meliaceae), International Journal of Pharmacy and Pharmaceutical Sciences 5 (2013) 104-107.

[10]. K.A. Reid, A.K. Jager, M.E. Light, D.A. Mulholland, J.V. Staden, Phytochemical and pharmacological screening of Sterculiaceae species and isolation of antibacterial compounds, Journals of Ethnophamacology 97 (2005) 285-291.

[11]. T. Odugbemi, Medicinal plants by species names: outlines and pictures of medicinal plants from Nigeria, p. 158, University of Lagos Press, 2006.

[12]. M. Sonibare, O. Micheal, O. Oyedokun, O. Oluwadayo, Phytochemical and antimicrobial studies of four species of Cola Schott \& Endl. (Sterculiaceae), African Journal of Traditional, Complementary and Alternative Medicines 6 (2009) 518-525.

[13]. J. Harborne. Phytochemical Methods. In: Harborne, J. B. (Ed.), A Guide to Modern Techniques of Plant Analysis. p. 279, Chapman and Hall, London 1973.

[14]. B.O. Opawale, A.M. Oyetayo, A.R. Agbaje. Phytochemical screening, antifungal and cytotoxic activities of Trichilia heudelotii Planc 
(Harm), International Journal of Sciences: Basic and Applied Research 24 (2015) 267-276.

[15]. T.I. Borokini, F.O. Omotayo. Phytochemical and ethnobotanical study of some selected medicinal plants from Nigeria, Journal of Medicinal Plants Research 6 (2012) 1106-1118. DOI: $10.5897 / J M P R 09.430$.

[16]. G.G.F. Nascimento, J. Locatelli, P.C. Freitas, G.L. Silva, Antibacterial activity of plant extracts and phytochemicals on antibiotic resistant bacteria, Brazil Journal of Microbiology 31 (2000) 247 - 256.

[17]. M. M. Cowan, Plant products as antimicrobial agents, Clinical Microbiology Review 12 (1999) $564-582$.

[18]. P.R. Cheeke, Nutritional and physiological implications of saponins - A review, Canadian Journal of Animal Science 51 (2008) 621-632.

[19] J.A. Ubon, M.I. Akpanabiatu, E.O. Akpanyung, U.F. Ufot, Effects of ethanolic extracts of Cola millenii $\mathrm{K}$. Schum seed on biochemical and toxicological indices of male wistar albino rats, Journal of Pharmacognosy and Phytochemistry 6 (2017) 160-166.

[20]. O.E. Giwa, F.O Onileke, I.A. Adesina, V.T. Adebote, Phytochemicals and antimicrobial properties of seed and pulp of Monkey Cola (Cola millenii) on some selected slinical and food borne isolate, International Journal of Applied Biology and Pharmaceutical Technology 3 (2012) 390-400.

[21]. I. Ajayi, O. Ojelere, Chemical composition of ten medicinal plant seeds from Southwest Nigeria, Advances in Life Science and Technology 10 (2013) 201-213.

[22]. D. Okwu, Phytochemicals, vitamins and mineral contents of two Nigeria medicinal plants,
International Journal of Molecular Medicine and Advance Sciences 1 (2005) 375-381.

[23]. B.A. Adeniyi, M.J. Groove, P.R.J. Gangadharam, In vitro anti-mycobacterial activities of three species of Cola plant extracts (Sterculiaceae), Phytotherapy Research 18 (2004) 414-418.

[24]. D.E. Okwu, M.E. Okwu. Chemical composition of Spondias mombin Linn. Plant parts, Journal Sustainable Agriculture and Environment 6 (2004) 140 - 147.

[25]. H.O. Edeoga, D.O. Eriata, Alkaloid, tannin and saponin contents of some Nigeria medicinal plants, Journal of Medicinal Aromatic Plant Science 23 (2001) 344-349

[26]. M.T. Olaleye, Cytotoxicity and antibacterial activity of methanolic extract of Hibiscus sabdariffa, Journal of Medicinal Plants Research 1 (2007) 009-013.

[27]. H.O. Edeoga, G. Omosun, L.C. Uche, Chemical composition of Hyptis suaveolens and Ocimum gratissimum hybrids from Nigeria, African Journal of Biotechnology 5 (2006) 892-895.

[28]. C. Kuoame, M. Sacande, Cola nitida (Vent.) Schott \& Endl. Seed Leaflet (2006) 111.

[29]. L. Manikandan, G.P. Senthilkumar, L.T. Rajesh, R. Suresh, Cancer chemoprotective agents from medicinal plants. In: Trivedi PC (ed). Medicinal Plants: Ethnobotanical approach, p. 410, Agrobios, India, 2006.

Received: 29.04.2018 Received in revised form: 03.06.2018 Accepted: 04.06.2018 